\title{
OPPORTUNITIES FOR SUSTAINABLE PRODUCTION OF ENERGY CROP MISCANTHUS IN SERBIA
}

\author{
Nikola Dražićc ${ }^{1 *}$ \\ Jelena Milovanović2, \\ Gordana Dražić2 \\ Eleonora Marišova ${ }^{3}$
}

${ }^{1}$ Faculty of Agriculture, University of Belgrade, Belgrade, Serbia ${ }^{2}$ Singidunum University, Belgrade, Serbia

${ }^{3}$ Slovak University of Agriculture in Nitra, Slovakia

\begin{abstract}
:
Bioenergy crops represent potential which lowers the country's dependence on oil imports and the emission of $\mathrm{CO}_{2}$ and contributes to the economic rural development. Miscanthus giganteus is the second generation agro energy crop suitable for cultivation in small agricultural households. The aim of this paper is to determine the economic advantages and limitations of $M$. giganteus production compared to the conventional production of maize in a small household in Serbia. The data are based on real yields achieved in the field during a nine-year experiment as well as prices from 2018. The experiment was carried out ona farm household which traditionally produces maize on the low fertility land with the use of their own basic machinery and storage space. Miscanthus production made for at least 30\% reduced expenditures and around $16 \%$ higher revenues compared to maize production. Significant obstacles to the production of miscanthus were identified, primarily the ones related to the underdevelopment of the biomass market in Serbia.
\end{abstract}

\section{Keywords:}

agriculture diversification, biomass, energy crops, low-quality land, rural development

\section{INTRODUCTION}

Bioenergy crops are a resource that reduces a country's dependence on oil and derivatives imports, contributes to climate change mitigation by reducing greenhouse gas emissions, and contributes to the economic development of rural areas (Mehui et al., 2017). An ideal energy crop should have adequate solar energy storage capacity in harvesting biomass with maximum efficiency, minimal abrasion, and minimal adverse environmental impacts (Kørup et al., 2017). Biomass crop cultivation systems must have a highly positive energy balance, that is, low energy expenditure relative to revenue, since energy expenditure actually involves the use of fossil fuels and carbon emissions in the atmosphere in the processes of cultivation, harvesting and especially nitrogen fertilization (Dierking et al., 2016; Germer et al., 2019). Numerous economic models have been developed for comparative energy cost analysis (Rodias et al., 2017). These models take a systematic approach to considering the production of biomass for energy use and are based on three distinct interrelated aspects: minimum price for energy crops cultivation, opportunity costs from utilizations of arable land for cultivation of crops for human or animal consumption and the substitution of fossil fuels or traditional forest biomass through demand analysis (Knapek et al., 2017).

Miscanthus gigantheus is the second-generation agro-energy crop. The extreme adaptability to adverse environmental conditions makes this energy crop suitable for production on low-quality land in the climatic conditions of our area, which is traditionally used for growing maize (Milovanovic et al., 2012). Investment restriction in the first year of plantation being used for up to 20 years by harvesting 
this aboveground plant with high biomass yields (8-40t/ ha/year) and its substantial energy value (lower thermal power $16 \mathrm{MG} / \mathrm{t}$ ) makes this crop suitable for cultivation in small agricultural households.

The aim of this study is to examine income and expenditure of miscanthus production in comparison to maize production. The real yields obtained in the field experiment were used for the consideration? of miscanthus for the period of 9 years, which was set up under the project TR 31078 "Ecoremediation of degraded areas by production of agro-energy crops" financed by the Ministry of Education, Science and Technological Development of the Republic of Serbia, as well as data from maize production in the observed household.

\section{METHODS}

\section{Perennial field trial}

Perennial field trial of miscanhtus with two variants (fertilization with $150 \mathrm{~kg} / \mathrm{ha}$ Nitogen: Phosphorus: Potassium (NPK) 15:15:15 in the year of establishment and without fertilization) on one's own soil of low quality type Planosol during 9 vegetation periods. The experiment was established in 2011 after standard pre-sowing preparation. Weed control was done mechanically in the first year of development.

\section{Yield determination}

The crop yield was measured in September of the going year when maximum yield is was obtained but aboveground biomass contained high percentage of moisture (50\%) and in late February or early March of the next year when yield was up to $30 \%$ lower due to natural drying of shoot biomass and falling leaves and the tips the stems during winter, when the harvested biomass had the best quality (Lewandowski and Heinz, 2003). For the calculations, the yield from the early spring harvest and the 2018 prices were used.

\section{RESULTS AND DISCUSSION}

Analysis of sustainable production of agro-energy crops requires a systematic approach in terms of land use for other purposes such as land for food production, pastures, industrial or service areas, recreation or disposal sites. Among that of the mentioned, agricultural land is the only real limiting factor. Therefore, the production of agro-energy crops should be organized primarily on degraded and marginal lands, although this leads to a significant decrease in yield and an increase in production costs (the European Environment Agency, EEA, 2013).There are 217682 small agricultural holdings in the Republic of Serbia that use up to 2 ha of agricultural land, while the average size of arable land is 4.5 ha per household. The house holders are on average 61 years old and only every fourteenth of them is under the age of 40 , while depopulation of the rural areas is becoming more and more pronounced (Stat. Gov. RS, 2019). Diversification of the rural economy includes, among others, raising awareness of the renewable energy sources importance and energy crops production (Strategy of Agricultural Development of the Republic of Serbia, 2014-2024). The production of agroenergy crops in Serbia is not sufficiently present because of lack of developed infrastructure for its use, except for some capacity utilizing first-generation biomass. In this paper we have analyzed the aspects of production of agro energy crop miscanthus from the point of view of small agricultural household in Serbia, in order to point out the advantages and disadvantages of this type of production in comparison to the production of a conventional crop - maize. In addition, the possible reasons why the production of biomass as a renewable energy source did not take effect will be discussed.

In our previous discussion we analyzed a real agricultural household that traditionally produces maize on relatively low fertility land (Dražić et al., 2017), has basic agricultural machinery including a low capacity pellet mill, storage area and 4.8 ha of arable land. A small field trial was established in the household with the aim of monitoring the development of aboveground biomass yield, in dry farming, as well as maize production, using basic fertilization of $150 \mathrm{~kg} / \mathrm{ha}$ NPK. The real yields obtained in the field trial over the course of 9 vegetation periods were calculated, calculated to 1 ha and prices from 2018 were used.

Expenses of maize and miscanthus production

Annual maize productions costs related to the entire production process from plot preparation to crop removal are shown in Table 1. 
Table 1- Costs of maize and miscanthus production per 1 ha $(€)$.

\begin{tabular}{|c|c|c|c|}
\hline \multicolumn{2}{|l|}{ Maize } & \multicolumn{2}{|l|}{ Miscanthus } \\
\hline \multicolumn{4}{|c|}{ Raw materials } \\
\hline Maize seeds (2.5 bags) & 124 & ${ }^{\star}$ Rhizomes (20000 pcs) & 3000 \\
\hline Mineral fertilizer $\mathrm{NPK}^{\star *} 15: 15: 15, \quad 300 \mathrm{~kg}$ & 118 & ${ }^{*}$ Mineral fertilizer NPK 15:15:15, $150 \mathrm{~kg}$ & 60 \\
\hline Mineral fertilizer $\mathrm{KAN}^{\star * \star}, 300 \mathrm{~kg}$ & 80 & & \\
\hline Weed protection products & 50 & & \\
\hline \multicolumn{4}{|c|}{ Mechanical works } \\
\hline Plowing & 65 & & \\
\hline Pre-sowing preparation $(2 \mathrm{x})$ & 42 & * Pre-sowing preparation $(2 \mathrm{x})$ & 42 \\
\hline Mineral fertilizer spreading $(2 \mathrm{x})$ & 25.5 & ${ }^{\star}$ Mineral fertilizer spreading $(1 \mathrm{x})$ & 13 \\
\hline Sowing & 20 & ^Planting & 40 \\
\hline A pesticide application $(2 \mathrm{x})$ & 22 & & \\
\hline Crop cultivation $(2 \mathrm{x})$ & 33 & ${ }^{\star}$ Crop cultivation $(2 \mathrm{x})$ & 33 \\
\hline Mowing & 91,5 & Mowing & 100 \\
\hline Transportation & 37 & Transportation & 37 \\
\hline Shredding harvesting debris & 30 & & \\
\hline \multicolumn{4}{|c|}{ Indirect expenditure } \\
\hline Tax & & & 13,2 \\
\hline Pension and disability insurance fund & & & 12.7 \\
\hline Land tenure & & & 230 \\
\hline
\end{tabular}

${ }^{\star}$ in the year of establishment only ${ }^{* \star N P K-N i t r o g e n ~ P h o s p h o r u s ~ P o t a s s i u m ~ ; ~}{ }^{* \star}$ KAN - Potassium ammonium nitrate

The prices in Table 1. are indicative and based on the cost of existing agricultural machinery, which is realistically old. The cost of producing maize on one's own land is around $€$ 742 , and on leased land around $€ 972$ per year. Assuming the prices remain the same for 20 years, the total cost of maize production would be $14832 €$. If the production has been done on a leased land for 20 years, $€ 19432$ is required.

For the establishment of miscanthus plantations at prices from the same year, with a rhizome price of 0.15 $€$ and a planting density of 20000 rhizomes/ha, $3060 €$ is necessary for the raw material, and direct planting costs $712 €$. In the year of establishment the yields are small, and therefore are not removed from the field, and in the coming years the cost of harvest is $137 € /$ ha with a yield of $10 \mathrm{t} / \mathrm{ha}$ (Tab. 2).Indirect costs of the maize production are the same and amount to around $€ 30$ on the parcel where maize is grown. Over the course of 20 years of miscanthus plantation, the total expenses on the parcel where miscanthus is grown are $3802 €$ for the first year $+3095 €(19$ years x 162.9 harvest and indirect costs) $=6897 €$.On the leased parcel the costs are increased by $4600 €$.

\section{Revenues from miscanthus and maize production}

The maize yields in the past 10 years have been $8-10$ $t / y r$, so an average value of $9 t / h a$ will be selected for the account; therefore, for a period of 20 years the maize grain yield is $180 \mathrm{t}$. Maize prices are subject to change depend- ing on the market and agro-politics, and $17.50 \mathrm{RSD} / \mathrm{kg}$ ratio was taken into consideration, providing total revenue of $25960 €$ for 20 years, assuming that the prices remain stable. During the production of maize grain, there is also a corn cob which weighs around one-third of the grain in our case, we get about $60 \mathrm{t} / \mathrm{ha}$ of cultivation over the period of 20 years, which can also be used as an energy source with lower heat value of $14.7 \mathrm{MJ} / \mathrm{kg}$.

The price refers to maize grain, so the use of electricity for the maize shredder should also be considered: it takes 10 hours for the machine to shred 1t of maize (stalk?), consuming $2 \mathrm{~kW}$ per hour, with total electricity consumption of $4000 \mathrm{~kW}$ for the period of 20 years.

On average, miscanthus yields $10 \mathrm{t} / \mathrm{ha} / \mathrm{yr}$ (Drazic et al., 2017); the yield in the first year after planting is negligible and shall not be included; the one in the second year is about $3.5 \mathrm{t} / \mathrm{ha}$, so in a 20 -year period we should expect a total yield of $3.5+18 \times 10 \mathrm{t} / \mathrm{ha}=183.5 \mathrm{t} / \mathrm{ha}$. Miscanthus yields are widely reported depending on agro-ecological conditions and applied agro-technical measures; a value of $0.9 t$ / ha of technically dry biomass can be taken as a realistic target to be achieved by 2050 in the UK (CliftonBrown et al., 2017), while in the USA yields of up to 44.5 $\mathrm{t} / \mathrm{ha}$ / year are projected (Heaton and Dohleman, 2008). On marginal soils, miscanthus yield varies significantly in (according to?) the function of soil quality, it can be up to $40 \%$ smaller on one soil and on others it can be the same as on a piece of fertile agricultural land (Dražić et al., 2017). 
Farmers could use miscanthus biomasses in their own households for heating purposes or they could sell it on the market, as is the case in some EU states (CliftonBrown et al 2017). So far the market for such biomass, chippings has not been developed in Serbia. Biomass is traded mostly in the form of pellets or briquettes. Wood pellets are available at a price of about $200 € / \mathrm{t}$, or from harvested residues (straw of wheat or soybeans) at a price of $130 € / t$, as well as serviceable pelleting of harvest residues at a ratio of 1:5 is also available ( $5 \mathrm{t}$ of straw for $1 \mathrm{t}$ of pellets). As there is no loss of biomass during pelleting, it can be calculated that in 20 years the revenue from 23855 to $36700 €$ should be realizable if the market is established.

However, pelleting also increases the cost because that part of the process is an energy hot spot (Perić et al., 2018). The pelletizer consumes $37-45 \mathrm{kWh}$ per hour and processes $350-500 \mathrm{~kg}$ of biomass inthat period of time. We will use the value of $40 \mathrm{~kW}$ and $400 \mathrm{~kg}$ of biomass for the calculation giving $40 \mathrm{~kW}: 400 \mathrm{~kg}=0.1 \mathrm{~kW} / \mathrm{kg}$. The costs related to the electricity consumed depend on the status of the user and other methods of consuming electricity (Tariff system), in accordance with the Tariff system for calculation of electricity for tariff customers.

If miscanthus biomass is used as energy for heating a household, the farmer will substitute about $10 \mathrm{~m} 3$ of firewood per year, which will require about $10 t$ of miscanthus biomass (given the thermal power and density of the heating material). This biomass can be produced on 1 ha of land.

Comparative analysis of income and expenditure of small plantation (1ha) of miscanthus and maize

Revenues and expenditures of maize and miscanthus production on a small privately owned parcel (1ha) in a farm household in the Republic of Serbia for the period of twenty years are presented in Table 2 .

Table 2 - Comparative overview of maize and miscanthus production costs and revenues per lha over the period of twenty years in farm household in Republic of Serbia $(€)$

\begin{tabular}{lll}
\hline Crop & Revenues & $\begin{array}{l}\text { Expendi- } \\
\text { tures }\end{array}$ \\
\hline Maize & $14832+4000 \mathrm{~kW}$ electric energy & $\begin{array}{l}25960+60 \\
\mathrm{t} \text { corn cobs }\end{array}$ \\
\hline Miscanthus & $6897+18000 \mathrm{~kW}$ electric energy & $\begin{array}{l}23855 \\
(36700)\end{array}$ \\
& &
\end{tabular}

In the $\mathrm{EU}$, the cost of planting perennial agro-energy crops is around $20-35 \%$, the cost of harvest is about 20 $30 \%$, and the cost of fertilizers is about $20-30 \%$ determines their minimum price, which is the deciding factor for the farmer to opt for the cultivation of these crops (Knapek et al., 2017), although it is also necessary to take into account the crop type, as well as climatic, pedological and socio-economic conditions of a particular region.
The cost of using a a leased-land property also plays a significant role, depending primarily on perennial grasses or short-flowing trees, whereas? labor and transportation have the least impact. According to LCCA (Life Cycle Costing Analysis) and DCF (Discounted Cash Flow) methodology, the estimated cost of production, drying and delivery to the market of 1 ton of miscanthus is 60$80 €(\sim$ US \$ 63-85) for marginal land (Soldatos, 2015). The recommended grain for cultivation in marginal fields is miscanthus because it is a perennial crop, adaptable to various climatic conditions, which gives high biomass yields with high energy power even with minimal use of mineral fertilizers, leaving a small amount of ash after combustion and producing a small amount of nitrous oxide. During the autumn harvest, yields may be used in biochemical conversion, giving high yields of bioethanol or biogas (Mehmood et al., 2017). The yield of 11t / ha of technologically dry mass of miscanthus is calculated to be a cut-off point for economic sustainability (Wagner et al., 2018).

In the $\mathrm{EU}$, the average yield of miscanthus is approximately $25 \mathrm{t} / \mathrm{ha}$ /year, with $15-20 \%$ moisture content (m.c.). The current miscanthus biomass price in the EU market is $€ 65-100 / t$ at $20 \%$ m.c. (Excl. VAT), depending on the member country. The calculation per hectare for one neighboring country - Croatia is given in Table 3. 
Table 3 - Miscanthus plantation income and expenses in Republic of Croatia $(€)$

\begin{tabular}{lccccccc}
\hline Year & 2019 & 2020 & 2021 & 2022 & 2023 & 2024 & $2025-2040$ \\
\hline $\begin{array}{l}\text { Yield } \\
\text { t/ha }\end{array}$ & 0 & 0 & 12 & 18 & 25 & 25 & 25 \\
\hline $\begin{array}{l}\text { Agricultural } \\
\text { operations }\end{array}$ & 967 & 200 & 302 & 386 & 484 & 484 & 726 \\
\hline $\begin{array}{l}\text { Cost of rhi- } \\
\text { zomes } €\end{array}$ & 2720 & 0 & 0 & 0 & 0 & 0 & 0 \\
$\begin{array}{l}\text { 1360/ha } \\
\text { Total costs }\end{array}$ & 3687 & 200 & 302 & 386 & 484 & 484 & 726 \\
\hline $\begin{array}{l}\text { Government } \\
\text { subsidy }\end{array}$ & 300 & 300 & 300 & 300 & 300 & 300 & 450 \\
\hline $\begin{array}{l}\text { Biomass sales } \\
\text { Total income }\end{array}$ & 0 & 0 & 780 & 1170 & 1625 & 1625 & 24735 \\
\hline $\begin{array}{l}\text { Net cash } \\
\text { flow€ }\end{array}$ & -3387 & -3287 & -2509 & -1425 & +16 & +1475 & +23072 \\
\hline
\end{tabular}

*plugging, disking, harrowing, planting, pesticides, mulching, mowing, bailing

Source: http://greenbiomassenergy.com/estimated-costs.html

The production of agro-energy crops over conventional has four average production on specific soil and in specific agroecological conditions, average cost of production, level of subsidies for conventional or agro-energy crops, and prices of conventional crops (Knapek et al., 2017). In the EU countries miscanthus yields are similar when the grain is cultivated in appropriate climatic conditions and when it comes to economic differences, prices differ only for land rent. From the perspective of a small farmer in Serbia, miscanthus yields are within the expected range, the cost of plantation establishment is somewhat lower, mostly due to low land rent, but there are no state subsidies for the production of agro-energy crops, and the market for this biomass has not been developed.

\section{CONCLUSION}

From the point of view of a small farmer in Serbia, which who owns about 5 ha of arable land on which maize is grown, a partial switch to the cultivation of miscanthus would means, for the long term in the long run, significantly less investment, increased income and less field involvement, which is not without significance insignificant given the rural population structure.

Land of a good quality should certainly continue to be used for food production and marginal lands should be used for energy crops. However, it is not possible to obtain a satisfactory yield on lower quality land. The yields achieved are on the verge of economic sustainability.

Significant obstacles to the determination of the a small farmer to produce agro-energy crops were identified, although miscanthus may be recommended. It is pri- marily related to the underdevelopment of the biomass market in Serbia, the absence of state stimulus measures for the production of agro-energy crops and the high cost of planting the plantation.

The setting up of large-scale agro-energy plantations, as opposed to cultivation in small households, may contribute more to rural development and poverty reduction in rural areas providing that the energy production chain from them is developed. From an environmental standpoint, the production of agro-energy crops preserves forests with their total values (economic, environmental and social) and contributes to the fight against climate change. For the valorization of agro-energy crops, it is not necessary to transform their market because the current situation leads to an excessive amount of crop residues from the fields and overuse of forests.

\section{ACKNOWLEDGEMENT}

Research was supported by the Ministry of Education, Science and Technological development of the Republic of Serbia (Project TR 31078 Ecoremediation of degraded areas by agroenergy crop production).

\section{REFERENCE}

1. Clifton-Brown, J. et al. (2017). Progress in upscaling Miscanthus biomass production for the European bio-economy with seed-based hybrids, $G C B$ Bioenergy 9, 6-17. doi: 10.1111/gcbb.12357

2. Dražić, G., Milovanović J., Ikanović, J., Petrić, I. (2017). Influence of fertilization on Miscanthus $\times$ 
giganteus (Greef et Deu) yield and biomass traits in three experiments in Serbia. Plant Soil Environment. 63, 189-193.

3. Dierking, R. M., Allen, D.J., Brouder, S.M., Volenec, J.J. (2016). Yield, biomass composition, and $\mathrm{N}$ use efficiency during establishment of four Miscanthus giganteus genotypes as influenced by $\mathrm{N}$ management. Biomass and Bioenergy, 91, 98-107

4. EEA (2013). Report 6/2013, EU bioenergy potential from a resource-efficiencies' perspective, ISSN 1725-9177, Luxembourg: Publications Office of the European Union, 60.

5. Gelfand, I., Sahajpal, R., Zhang, X., Izaurralde R.C., Gross, K.L., Robertson, P. (2013). Sustainable bioenergy production from marginal lands in the US Midwest.

6. Nature, 493, 514-5017.

7. Germer, S., Aleksopoulou, E., et al (2019). Innovative lignocellulosic cropping systems in europe: combining knowledge from several EU-projects, 27th European Conference and Exhibition, 27-30 May 2019, Lisbon, Portugal, https://www.researchgate.net/publication/335175605_ (20.08.2019)

8. Heaton E.A., Dohleman F.G., Long S.P. (2008). Meeting U.S. biofuel goals with less land: the potential of Miscanthus. Global Change Biology, 14, 2000-2014

9. Knápek, J., Vávrová, K., Valentová, M., Vašícek, J., Králík, T. (2017). Energy biomass competitiveness - three different views on biomass price. WIREs Energy Environ, 6, 1-13. doi: 10.1002/ wene. 261

10. Kørup, K, Lærke, P., Baadsgaard, H., Andersen, M., Kristensen, K., Meunnich, C., Didion, T., Jensen, E., Artensson, L., Jørgensen, U. (2017). Biomass production and water use efficiency in perennial grasses during and after drought stress. GCB Bioenergy doi: 10.1111/gcbb.12464

11. Lewandowski, I., Heinz A. (2003): Delayed harvest of Miscanthus-influences on biomass quantity and quality and environmental impacts of energy production. European Journal of Agronomy, 19, 45-63.

12. Mehmooda, M., A., Ibrahimb, M., Rashidc, U., Nawazd, M., Alib, S., Hussaina, A., Gulle. M. (2017). Biomass production for bioenergy using marginal lands. Sustainable Production and Consumption, 9, 3-21.

13. Meihui, L. Na, L., and Yi, L. (2017). Biomass Energy Technological Paradigm (BETP): Trends in This Sector, Sustainability, 9. 567.

14. Milovanović, J., Dražić, G., Ikanović, J., Jurekova, Z., Rajković, S. (2012). Sustainable production of biomass through Miscanthus giganteus plantan- tion development. Annals of Faculty Engineering Hunedoara International Journal of Engineering 10, 79-82.

15. Perić, M., Komatina, M., Antonijević, D., Bugarski, B., Dželetović, Ž. (2018). Life Cycle Impact Assessment of Miscanthus Crop for Sustainable Household Heating in Serbia. Forests, 9, 654-680.

16. Rodias, E., Berruto, E., Bochtis, D., Busato, P., Sopegno, A. (2017). A Computational Tool for Comparative Energy Cost Analysis of Multiple-Crop Production Systems. Energies, 10, 831; doi:10.3390/ en10070831

17. Soldatos, P., 2015. Economic aspects of bioenergy production from perennial grasses in marginal lands of South Europe. BioEnergy Res. 8, 1562-1573.

18. Statistical Office of the Republic of Serbia (2019). The survey on the structure of agricultural households 2018. http://publikacije.stat.gov.rs/G2019/ Pdf/G201918010.pdf

19. The Government of the Republic of Serbia. (2014). Strategy for Agriculture and Rural Development of the Republic of Serbia for the period 20142024 ("Official Gazette" of the Republic of Serbia No.85/2014.)

20. Wagner, M., Mangold, A., Lask, J., Petig, E., Kiesel, A., Lewandowski, I. ( 2018). Economic and environmental performance of miscanthus cultivated on marginal land for biogas production, $G C B$ Bioenergy https://doi.org/10.1111/gcbb.12567

21. http://greenbiomassenergy.com/estimated-costs. html (24. 09. 2019) 